\title{
Gold Nanoparticles from Ostruthin: Green Synthesis, a Stable Mechanism, Antitumor, and Antibacterial Activity
}

\author{
AN TRAN NGUYEN MINH ${ }^{1 *}$, CUONG NGUYEN VAN ${ }^{1}$, QUANG NGUYEN MINH', \\ TRI MAI DINH ${ }^{2,3}$, ALAM MAHBOOB ${ }^{4}$ \\ ${ }^{1}$ Faculty of Chemical Engineering Industrial University of Ho Chi Minh City, Ho Chi Minh city, Vietnam, 12 Nguyen Van \\ Bao Road, Ward 4, Go Vap District, Ho Chi Minh City, 700000, Vietnam \\ ${ }^{2}$ Institute of Chemical Technology, Vietnam Academy of Science and Technology, Ho Chi Minh City, Vietnam, 01 Mac \\ Dinh Chi Road, 1 Disctrict, Ho Chi Minh City, 700000, Vietnam \\ ${ }^{3}$ Graduate University of Science and Technology, Vietnam Academy of Science and Technology, Hanoi, Vietnam, 18 \\ Hoang Quoc Viet Road, Cau Giay District, Hanoi City, 100000, Vietnam \\ ${ }^{4}$ Division of Chemistry and Biotechnology, Dongguk University, Gyeongju 780-714, Republic of Korea
}

\begin{abstract}
The Ostruthin was extracted and identified its structure from rhizomes of Luvunga scandens located at $\mathrm{Ta} \mathrm{Cu}$ Mountain, Binh Thuan province, Vietnam for the first time. Gold nanoparticles (AuNPs) were synthesized by the green method. The AuNPs acted as antitumor against breast cancer cell line (MCF-7), human liver cancer cell line (HepG2), and Non-Small Cell Lung (NCI-H460). They showed the potential antitumor activity against MCF-7 with the IC50 value of $65.47 \pm 3.09 \mu \mathrm{M}$. The antitumor activity of the AuNPs was also compared with the extracted constituents from the root of Luvunga Scandens in a previous article. The AuNPs were exposed to high antitumor activity against MCF-7 and Hep G2, human cancer cell lines. The AuNPs have also been tested the antibacterial activity and shown the moderate antibacterial activity on both Salmonella enterica and Bacillus subtilis at a concentration of $0.25 \mathrm{mM}$.
\end{abstract}

Keywords: Ostruthin, Biosynthesis, Gold nanoparticles, antitumor, Antibacterial activity.

\section{Introduction}

The metallic nanoparticle has been found in the medical section due to multiple advantages: the usage of nanoparticles as drug delivery systems to potential the therapeutic action of a phytochemical agent, myriad applications in cancer therapy [1,2]. The AuNPs are precious, inert, and not oxidized easily being exposed to oxygen or high acidity environments [3]. There are many applications in the biomedical field as antimicrobial activities, stabilizing with proteins, and peptides [4]. The synthesis of AuNPs can perform on using green route methods according to their cytotoxicity and electrochemical activity [5-8], inflammation [9], and antimicrobial activities [10]. Many articles have been reported to synthesize gold and silver nano from extracted plants and gold and silver ions and apply in medical chemistry [11-13]. Many chemical methods conducted on the synthesis involving reduction of gold cations $\left(\mathrm{Au}^{3+}\right)$ to $\mathrm{Au}$ with chemical reducing agents or other organic compounds. These methods were either expensive or environmentally hazardous, but they were easier to control the shape and size by varying synthesis conditions, stability, and catalyst applications $[14,15]$. Recent, several studies have shown approaching green chemistry, which was a type of reducing agent from plant extracts $[16,17]$. The mechanism of the biochemistry method showed that $\mathrm{Au}^{3+}$ ions (oxidizing agent) reacted with biological molecules from plant extracts, which provided proteins, amino acids, enzymes, polysaccharide, alkaloid, tannin, phenol, saponin, terpenoids, and vitamins. These molecules added with both electrostatic stability and reducing agents at the biochemistry synthesis $[18,19]$. Besides, the properties of AuNPs were determined according to some parameters like the forming time of the AuNPs, temperature, $p \mathrm{H}$, the concentration of gold ions, [20, 21] nature and morphology of $\mathrm{Au}$ structures [22]. The Than Xa Huong plant was named scientific Luvunga scandens (Roxb.) Buch. Ham and the traditional medicinal plants have been conducted in the treatments of cirrhosis, rheumatism, scorpion bite, hepatitis, sinusitis, pain in bone joints, and muscles.

\footnotetext{
*email: trannguyenminhan@iuh.edu.vn
} 
The rhizomes of Luvunga scandens have been characteristics of cytotoxicity and antioxidant [2325]. Because of the interested bioactivities on both traditional medicine and pharmaceutical chemistry compounds being extracted from Luvunga scanden, the AuNPs were synthesized by greener reducing method that specially carried out the reaction with only one pure extract compound from Luvunga scandens via redox reaction with advanced sites. We continuously extracted rhizomes of Luvunga scandens at $\mathrm{Ta} \mathrm{Cu}$ Mountain, Binh Thuan province, Vietnam using $n$-hexane solvent. The fraction that was made in our previous paper [26], isolated Ostruthin performed a reduced reaction, and proved the new role of Ostruthin as the well green reducing agent forming the AuNPs that can apply to medicinal chemistry and cosmetics, made easy reactions, save elements, and drug delivery. They have performed the antibacterial activity and the antitumor on three human cancer cell lines in vitro because the AuNPs via green approach can be applied to the human body, drug delivery systems.

\section{Materials and methods}

\subsection{Materials}

The rhizomes of $L$. scandens were collected in Ta $\mathrm{Cu}$ Mountain, Binh Thuan province, Vietnam, and identified by Dr. Luu Hong Truong, Southern Institute of Ecology, Vietnam Academy of Science and Technology. The specimen sample (Code LS-128) was stored in Bioactive Compounds Laboratory, Institute of Chemical Technology, Vietnam Academy of Science and Technology, Vietnam. The gold (III) chloride trihydrate $\left(\mathrm{HAuCl}_{4}\right)$ was supplied by Sigma-Aldrich company. The Bacillus cereus, Bacillus subtilis, Escherichia coli, and Salmonella enterica were grown at the lab of biochemistry, Vietnam. Mueller-Hinton and potato dextrose agar were purchased from DIFCO Laboratories, MI, USA.

The high-resolution electrospray ionization mass spectrometric analysis (HR-ESI-MS) was performed using a Bruker MicroTOF-QII spectrometer (Bruker Daltonik GmbH, Bremen, Germany). The ${ }^{1} \mathrm{H}-\mathrm{NMR}(500 \mathrm{MHz}),{ }^{13} \mathrm{C}-\mathrm{NMR}(125 \mathrm{MHz})$, DEPT, HSQC, and HMBC spectra recorded on a Bruker AM500 FT-NMR spectrometer using tetramethyl silane (TMS) as an internal standard. Column chromatography was checked using silica gel normal-phase (230-400 mesh). The analytical TLC was performed in silica gel plates (Kieselgel 60 F254, Merck). The UV-Vis spectral analysis performed with a Cary- 4000 spectrophotometer. The TEM image managed using JEM-1400, JEOL model. The FT-IR spectrum measured on Bruker-Germany equipment. The Zeta potential and the hydrodynamic diameter of the particles were determined using a Malvern Zetasizer Nanoseries compact scattering spectrometer (Malvern instruments Ltd., UK). The XRD and EDX were recorded on model 6100 and 8100, respectively. The morphology of the prepared AuNPs observed by the TEM image.

\subsection{Methods}

\subsubsection{Extraction Ostruthin from rhizomes of Luvunga scandens}

The powdered rhizomes of $L$. scandens $(5.0 \mathrm{~kg})$ were extracted three times with $30 \mathrm{~L}$ of $96 \%$ ethanol at room temperature. The residue was filtered, and the solvent was evaporated to obtain the crude extract $(350 \mathrm{~g})$. The crude extract was dissolved in water and successively partitioned into $n$ hexane $(120 \mathrm{~g}, 2.4 \%)$, chloroform $(80 \mathrm{~g}, 1.6 \%)$, ethyl acetate $(30 \mathrm{~g}, 0.6 \%)$ and the aqueous portion $(110 \mathrm{~g})$. The $n$-hexane extract $(120 \mathrm{~g})$ was fractionated on a silica gel column with $n$-hexane: ethyl acetate $(\mathrm{v}: \mathrm{v}=50: 1,20: 1,10: 1,5: 1$ and $1: 1)$ by increase the amount to $100 \%$ of ethyl acetate to give six fractions which were labeled F.1 to F.6. The fraction (F.2) collected the crude solid, which was washed with $n$-hexane: acetone (v: v=1:1) to obtain the light-yellow crude solid after filtration. The $31.25 \mathrm{~g}$ of crude solid recrystallized by adding $40 \mathrm{~mL}$ of dichloromethane and $40 \mathrm{~mL}$ of $n$-hexane sequence and collected $27.34 \mathrm{~g}(0.55 \%)$ of the impure solid after completion filtration. The $27.34 \mathrm{~g}$ of impure solid was continued to separate by normal phase chromatography column with a dynamic phase, which was $n$-hexane: ethyl acetate $(\mathrm{v} / \mathrm{v}=5: 1)$. The pure solid was obtained $18.59 \mathrm{~g}(0.38 \%)$ of pure Ostruthin. 


\subsubsection{The green synthesis of the AuNPs}

The $6.70 \mathrm{mM}$ of the pure Ostruthin was prepared by adding $0.1 \mathrm{~g}$ of the Ostruthin to $50 \mathrm{~mL}$ of $95 \%$ ethanol. The $5 \mathrm{~mL}$ of $6.70 \mathrm{mM}$ Ostruthin was added to $50 \mathrm{~mL}$ of $1 \mathrm{mM}$ Gold (III) chloride trihydrate solution. The temperature of Gold (III) chloride trihydrate solution in Ostruthin was increased from 30 to $70^{\circ} \mathrm{C}$ with multiple of $10^{\circ} \mathrm{C}$ for every temperature reading. The changes in the colour of the solution observed at $(5,10,20,30$, and $60 \mathrm{~min})$ of every reaction time.

\subsubsection{Antimicrobial activity}

The antibacterial activity was assessed based on the previous articles without significant changes $[27,28]$. The AuNPs were tested for antimicrobial activity by disk-diffusion assay against Salmonella enterica, Bacillus substilis, Escherichia coli, and Bacillus cereus bacterium. The $300 \mu \mathrm{L}$ of test organisms was added in $10 \mathrm{~mL}$ of the nutrient broth solution, which obtained $1 \times 10^{6} \mathrm{CFU} \mathrm{\textrm {mL } ^ { - 1 }}$ of each organism. They were grown in an incubator for $24 \mathrm{~h}$ at $37^{\circ} \mathrm{C}$. Muller-Hinton agar (MHA) was prepared media using bacteria. The wells of $5 \mathrm{~mm}$ diameter were made on MHA gel disks. Each strain was swabbed uniformly into the individual plate using a sterile cotton swab. The AuNPs were prepared in concentrations of $0.125,0.25,0.5$, and $1 \mathrm{mM}$ and Gentamicin at a concentration of $1 \mathrm{mg}$. $\mathrm{L}^{-1}$ ) for testing antimicrobial activity. Using a sterile micropipette $30 \mu \mathrm{L}$ of the sample of the AuNPs or standard drug poured onto each of a well. After incubation at $35^{\circ} \mathrm{C}$ for $24 \mathrm{~h}$, the different levels of a zone of inhibition were measured using the meter scale.

\subsubsection{Antitumor activity of AuNPs}

The antitumor of AuNPs was screened based on Sulforhodamine B colorimetric assay (SRB) [29]. The sulforhodamine B (SRB) assay is conducted for cell density determination, based on the measurement of cellular protein content. The method has been optimized for the toxicity screening of compounds to adherent cells in a 96-well format. The method not only allows many samples to be tested within a few days but also requires only simple equipment and inexpensive reagents. The SRB assay is, therefore, an efficient and highly cost-effective method for screening. The assay was performed as previously described with some modifications. Cells, seeded at a density of 10,000 cells/well (MCF-7, Hep G2) or 7,500 cells/well (NCI-H460) in 96-well plates were cultured for $24 \mathrm{~h}$ before being incubated with AuNPs at different concentrations for $48 \mathrm{~h}$. Treated cells were fixed with cold $50 \%(\mathrm{w} / \mathrm{v})$ trichloroacetic acid (Merck) solution for $1-3 \mathrm{~h}$, washed and stained with $0.2 \%(\mathrm{w} / \mathrm{v})$ SRB (Sigma) for $20 \mathrm{~min}$. After five times washed with $1 \%$ acetic acid (Merck), the protein-bound dye was solubilized in $10 \mathrm{mM}$ Tris base solution (Promega). Optical density values were determined with a 96-well microtiter plate reader (Synergy HT, Biotek Instruments) at the wavelengths of $492 \mathrm{~nm}$ and $620 \mathrm{~nm}$. The percentage of growth inhibition (Inh \%) was calculated according to the formula: Inh $\%=$ (1-[ODt/ODc] $) \times 100 \%,[30-32]$, in which ODt and ODc were the optical density value of the test sample and the control sample, respectively. Camptothecin was used as a positive control. The antitumor activity in vitro of AuNPs was performed at differential concentrations against breast cancer cell line (MCF-7), NCI H460 (Non-Small Cell Lung), and Hep G2 (human liver cancer cell line) by RSB assay.

\section{Results and discussions}

\subsection{The physical chemistry of Ostruthin}

\subsubsection{The FT-IR spectra}

Figure S1 showed the FT-IR spectra displayed the infrared absorption peaks at $3156 \mathrm{~cm}^{-1}(\mathrm{OH})$, $2968 \mathrm{~cm}^{-1}, 2917 \mathrm{~cm}^{-1}$ (C-H), $1684 \mathrm{~cm}^{-1}, 1605 \mathrm{~cm}^{-1}(\mathrm{C}=\mathrm{O}), 1570 \mathrm{~cm}^{-1}, 1445 \mathrm{~cm}^{-1}$ and $1390 \mathrm{~cm}^{-1}(\mathrm{C}=\mathrm{C})$, $1271 \mathrm{~cm}^{-1}$ and $1237 \mathrm{~cm}^{-1}(\mathrm{C}-\mathrm{O})$. 


\subsection{2. ${ }^{1} \mathrm{H}-\mathrm{NMR}$ spectrum}

As indicated in Figure S2-4, the ${ }^{1} \mathrm{H}$ - NMR spectrum appeared 13 resonance signals which are related to 22 protons. One resonance signal of the singlet hydroxyl group appeared at $8.16 \mathrm{ppm}(1 \mathrm{H}$, brs, 7-OH) and there were eight resonance signals of geranyl group including 2 protons of 2 alkene groups at $5.34\left(\mathrm{t}, J=7.3 \mathrm{~Hz}, 1 \mathrm{H}, \mathrm{H}-2^{\prime}\right), 5.10\left(\mathrm{t}, J=6.3 \mathrm{~Hz}, 1 \mathrm{H}, \mathrm{H}-6^{\prime}\right), 3$ methyl groups at $1.72(\mathrm{~s}, 3 \mathrm{H}$, $\left.\mathrm{C}_{3}, \mathrm{H}-8^{\prime}\right), 1.68$ (s, 3H, $\left.\mathrm{C}_{3}, \mathrm{H}-10^{\prime}\right), 1.60$ (s, 3H, $\left.\mathrm{C}_{3}, \mathrm{H}_{-} 9^{\prime}\right)$. The 3 methylene groups indicated resonance peaks at $3.39\left(\mathrm{~d}, J=7.5 \mathrm{~Hz}, 2 \mathrm{H}, \mathrm{C}_{2}, \mathrm{H}-1\right.$ ' $), 2.07-2.10\left(\mathrm{~m}, 2 \mathrm{H}, \underline{\mathrm{C}}_{2}, \mathrm{H}-4^{\prime}\right)$ and 2.11-2.13 (m, $\left.2 \mathrm{H}, \mathrm{C}_{2}, \mathrm{H}-5^{\prime}\right)$. The skeleton of coumarin has four resonance signals including two olefin protons having been coupling cis at $7.66(1 \mathrm{H}, \mathrm{d}, J=9.0 \mathrm{~Hz}, \mathrm{H}-4), 6.23(1 \mathrm{H}, \mathrm{d}, J=9.5 \mathrm{~Hz}, \mathrm{H}-3)$ and two aromatic protons indicated at $7.20(\mathrm{~s}, 1 \mathrm{H}, \mathrm{H}-5)$ and $7.09(\mathrm{~s}, 1 \mathrm{H}, \mathrm{H}-8)$.

\subsubsection{The ${ }^{13} \mathrm{C}-\mathrm{NMR}$ and DEPT spectra}

The ${ }^{13}$ C-NMR had 19 signals as shown in Figure S5-6, and DEPT presented in Figure S7-8 spectra exposed 3 methyl carbons at (16.1, 17.7 and 25.7), 3 methylene carbons at (26.5, 27.9 and 39.7), 6 methine carbons at $(103.0,111.7,121.0,124.0,128.1$ and 144.7) and 7 quaternary carbons $(112.1$, $126.4,131.6,138.1,154.0,159$ and 163.0). The exception of ten resonance signals of one geranyl group, the skeleton of coumarin remained nine signals including one signal of a carbonyl carbon atom at $162.9(\mathrm{C}-2, \mathrm{C}=\mathrm{O})$, four $s p^{2}$ - carbon signals at $144.7(\mathrm{C}-4), 128.1(\mathrm{C}-5), 111.7(\mathrm{C}-3)$ and $103.0(\mathrm{C}-8)$. Two $s p^{2}$ - carbon signals bearing atomic oxygen appeared at 158.9 (C-7), and 154.0 (C-9). Two quaternary carbon signals were assigned at $126.4(\mathrm{C}-6)$ and $112.0(\mathrm{C}-10)$. Ten carbon signals of the geranyl group pointed out two $s p^{2}$ - carbon signals at 124.0 (C-6'), 121.0 (C-2'), 2 quaternary carbon signals at 138.1 (C-3'), 131.6 (C-7'), three methylene groups at 39.7 (C-4'), 27.9 (C-1'), 26.5 (C-5'), and three methyl groups at 25.7 (C-10'), 17.7 (C-9'), and 16.1 (C-8').

\subsubsection{The HMBC, HSQC and HR-MS spectra}

As shown in Figure S9-13 of the HMBC spectrum, the $\mathrm{H}-4$ proton at $7.66(1 \mathrm{H}, \mathrm{d}, 9.0 \mathrm{~Hz})$ correlated to aromatic ring carbons, C-5 (128.1) and C-9 (154.0). The H-3 proton corresponded to C-2 and $\mathrm{C}-10$. The $\mathrm{H}-5$ proton related to the one methylene carbon, C-1' (27.5) and two carbon signals of aromatic ring bearing oxygens were classified C-7 (159.0) and C-9 (154.0). The H-1' proton was compatible with carbons as C-5, C-6, C-7, C-2', and C-3'. The H-2' proton was consistent with C-6, C-1', C-4', and C-8'. Those correlations demonstrated the geranyl group attached to C-6 and the hydroxy group linked to C-7 in Figure 1. The HR-MS (ESI) spectrum indicated in Figure S17 the experiment value, $[\mathrm{M}+\mathrm{H}]^{+}=299.1683$ and the calculation value, $[\mathrm{M}+\mathrm{H}]^{+}=299.1647$. Based on spectra data of FT-IR, ${ }^{1} \mathrm{H},{ }^{13} \mathrm{C}-\mathrm{NMR}$, DEPT, HMBC, and HSQC Figure S14-16 and explained data as shown in Table $\mathbf{S 1}$ provided the Ostruthin in Figure 1.

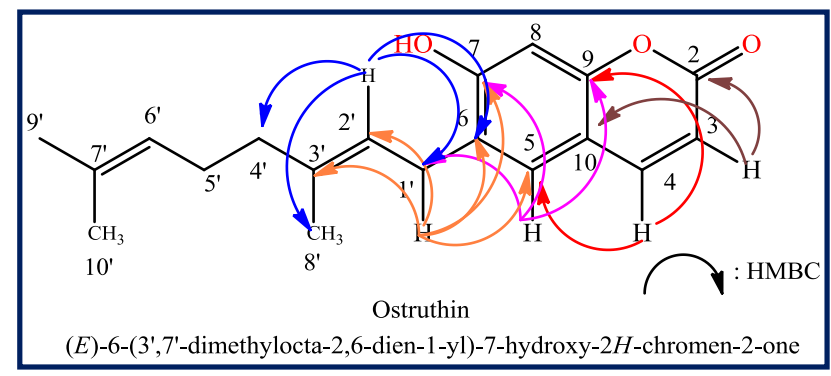

Figure 1. The structure of Ostruthin was indentifed by IR, NMR, HSQC and HMBC and HR-MS spectrum

\subsection{The characterization of AuNPs}

\subsubsection{Ultraviolet-visible (UV-vis) spectroscopy for determination of formation of AuNPs}

The UV-vis spectrum determined the formation and size of gold nanoparticles in aqueous solution. The UV-vis spectrum of the AuNPs indicated the Ostruthin solution before reacting with gold salts did 
not appear peak as shown in Figure $2 \mathrm{~b}$ with a yellow line in graph and appeared one peak of $535 \mathrm{~nm}$ in the wavelength range of 300 to $800 \mathrm{~nm}$ in Figure 2b, black line. The maximum absorption of the solution was at $548 \mathrm{~nm}$ being demonstrated colloidal dispersion system of the AuNPs formed. The synthesized AuNPs made a surface Plasmon Resonance (SPR) which caused the color change and also appeared a maximum absorption peak in the visible region. The absorption peak that caused the plasmon resonance peak of AuNPs depended on the shape, size, crystallinity, and nature of the nanoparticles. As presented in Figure 2b, the highest absorbance at a wavelength of $548 \mathrm{~nm}$ and the intensity of the absorption band increased with an increasing time period from 15 to 40 min and displayed without significant difference of absorption band from above 40 to $60 \mathrm{~min}$. In the first step, the effect of reaction times was determined and they fully completed during a reaction time of $30 \mathrm{~min}$.

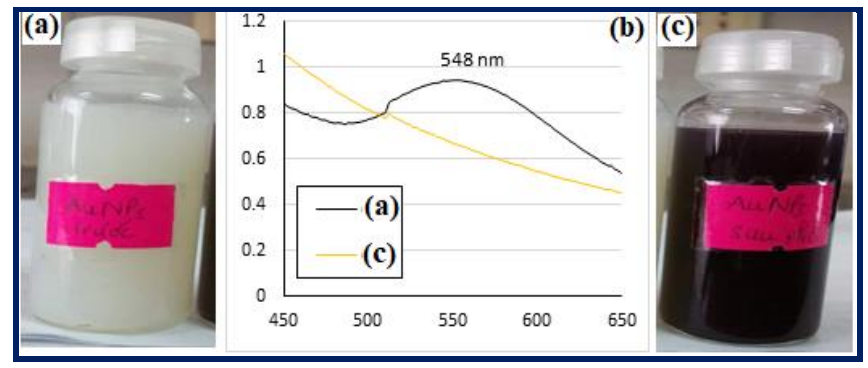

Figure 2. (a): Ostruthin solution and $\mathrm{HAuCl}_{4}$, (b): The UV-Visible spectroscopy of (c) solution, and (c): the color change of (a) solution after exposing to the sunlight at $30 \mathrm{~min}$

\subsubsection{Effects of temperatures on the biosynthesis of the AuNPs}

The color of the AuNPs changed when temperatures change between 30 and $70^{\circ} \mathrm{C}$ in Figure 3 . They were initiated with the light color, aggregation, and sedimentation at $70^{\circ} \mathrm{C}$. The spectrum of them shifted absorbance peak as the temperature change. The intensity of the absorption band increased with increasing temperature from 30 to $50^{\circ} \mathrm{C}$ being made increasing in the reaction rate of the conversion of the $\mathrm{Au}^{3+}$ ion to $\mathrm{Au}$ atom due to the decreasing active energy reaction. The intensity of the absorption band decreased on which the temperature of reaction increased from about 60 to $70^{\circ} \mathrm{C}$. When the temperature installed higher than $50^{\circ} \mathrm{C}$, the Brown motion was stronger, which made random motions of the AuNPs to increase the probability of collisions between colloidal particles and possibly more aggregation and sedimentation. When the temperature increased, the widths of diffuse layers also extended, and the Zeta potential increased to the range of $-30 \mathrm{mV}$ to $+30 \mathrm{mV}$ leading to the sedimentation of the AuNPs.

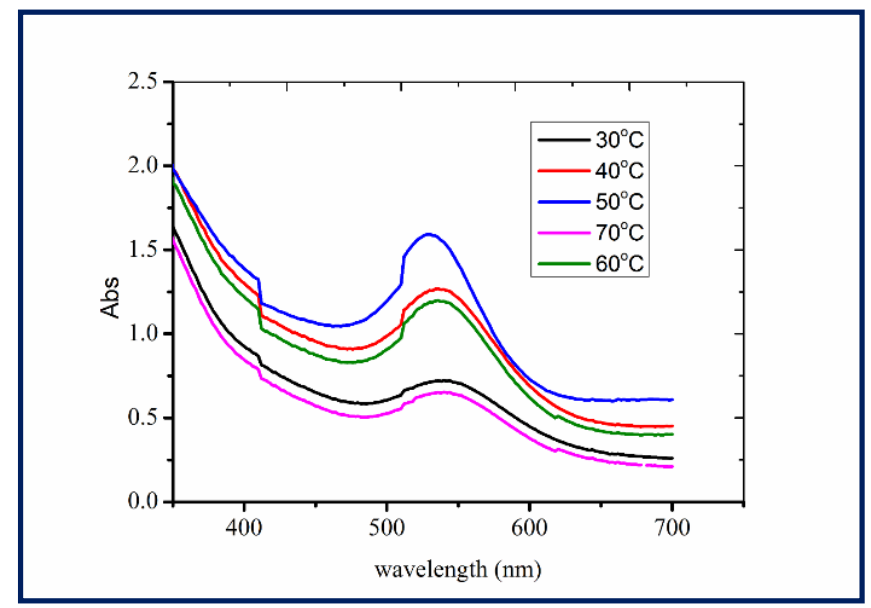

Figure 3. The effects of temperatures on forming the AuNPs 


\subsubsection{The effect of times on the biosynthesis of the AuNPs}

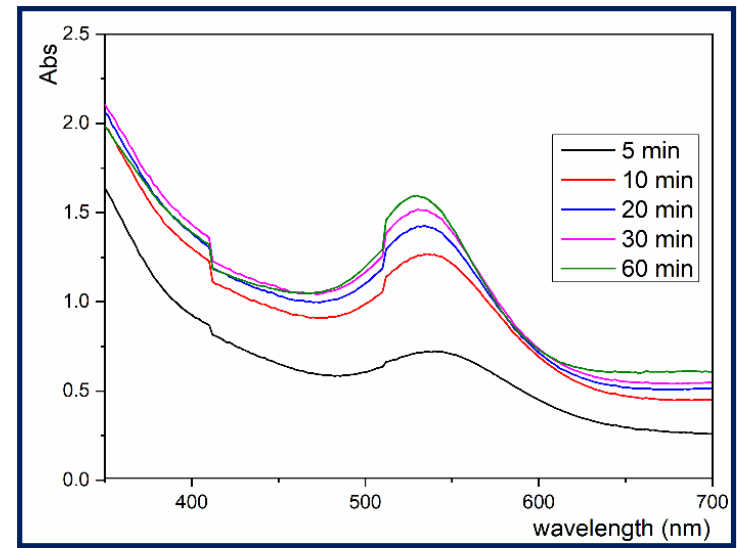

Figue 4a. The effects of times on forming the AuNPs

The UV-vis spectrum showed that Osthuthin solution before adding $\mathrm{HAuCl}_{4}$ did not appear peak and after adding $\mathrm{HAuCl}_{4}$ solution and exposing to the sunlight appeared the maximum absorption, $\lambda_{\max }$ in the wavelength range of $500-550 \mathrm{~nm}$. The absorption rate $\left(\mathrm{A}_{\max }\right)$ at the $\lambda_{\max }$ in the range of 500 to $550 \mathrm{~nm}$ increased rapidly up to $30 \mathrm{~min}$ and from above 30 to $70 \mathrm{~min}$ of reaction time, as shown in Figure 4a, the color of the AuNPs has not changed too much, bold purple with the constant absorption wavelength. The synthesized AuNPs nanoparticles created a surface plasmon resonance (SPR), which made the effect on the color change of the AuNPs, the darker the color, the more forming AuNPs, smaller the particle size, as shown in Figure 4b.

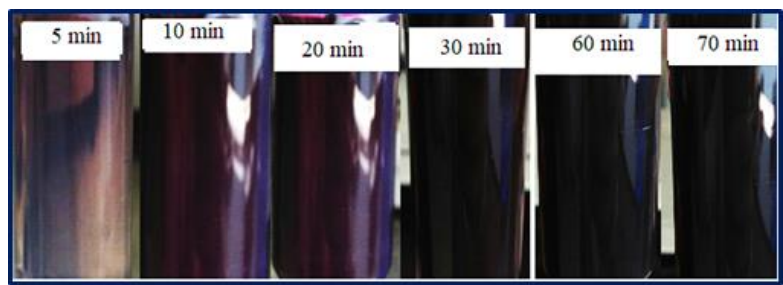

Figure 4b. The color change of the AuNPs at interval times

\subsubsection{The effect of concentration on the forming of the AuNPs}

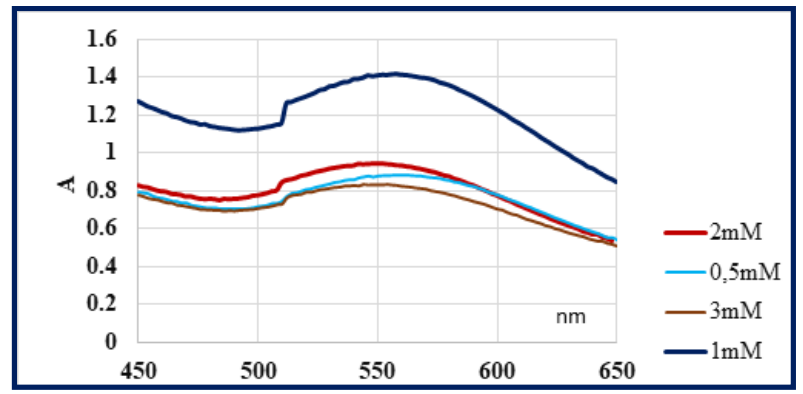

Figue 5. The effect of concentrations of the AuNPs to absorption rates

As shown in Figure 5, the UV-vis spectrum of AuNPs indicated the absorption rates at concentrations of $0.5,1,2$, and $3 \mathrm{mM}$. The maximum UV absorption performed at $1 \mathrm{mM}, 548 \mathrm{~nm}$, exposure time under the sunlight of $40 \mathrm{~min}$. The optimum UV-vis spectrum created the optimal AuNPs for $30 \mathrm{~min}, p \mathrm{H} 4$, and a concentration of the AuNPs of 1mM, which was dark purple.

\subsubsection{Fourier transform infrared (FT-IR) spectrum of the AuNPs}


The FT-IR spectrum of the AuNPs as shown the infrared absorption peaks in Figure S18. The presences of characteristic functional groups which formed in reduction between Ostruthin and $\mathrm{Au}$ (III) were peaks at $3420 \mathrm{~cm}^{-1}$ (OH of alcohol, phenol or $\mathrm{OH}$ of water), $1651 \mathrm{~cm}^{-1}(\mathrm{C}=\mathrm{O}$, lactone), and $741 \mathrm{~cm}^{-1}$ (aromatic bearing substitution at C-7, C-6). The absence of absorption peaks at $1589 \mathrm{~cm}^{-1}$, $1445 \mathrm{~cm}^{-1}$, and $1390 \mathrm{~cm}^{-1}(\mathrm{C}=\mathrm{C}) \mathrm{cm}^{-1}$ in Ostruthin proved to transform functional groups of two alkene groups to functional groups of a tertiary alcohol in water media.

\subsubsection{The XRD of the AuNPs}

The XRD of the AuNPs: The extracted Ostruthin solid carried out in the green redox reaction for the transform of $\mathrm{Au}^{3+}$ ion to $\mathrm{Au}$ atoms which were verified by Bragg peaks at $38.4^{\circ}, 44.6^{\circ}, 64.8^{\circ}$, and $77.5^{\circ}$ and agreed with those values reported in literature JCPDS No.04-0784 being corresponding to (111), (200), (220) and (311) sets of lattice planes in Figure 6. They were indexed as face-centered cubic (FCC) structures of gold. The X-ray diffraction (XRD) results clearly indicated the AuNPs formed by the reduction of $\mathrm{Au}^{3+}$ ions to $\mathrm{Au}$ ions by reduction Ostruthin compound [33].

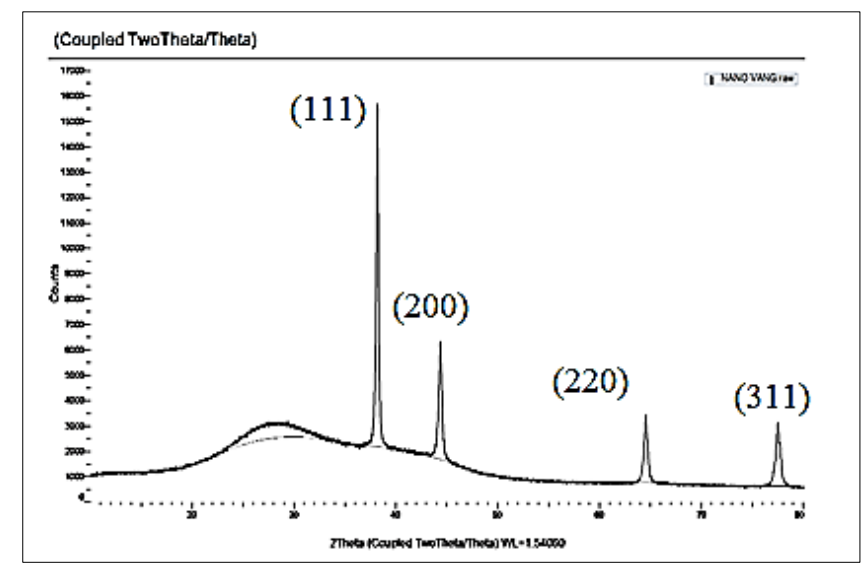

Figure 6. The X-ray diffusion spectrum of the AuNPs for 30 min of reaction time

\subsubsection{The Zeta potential and stable dispersion system of AuNPs}

In Figure 7, the AuNPs were synthesized and kept in 14 days. The Zeta potential value was measured $+30.3 \mathrm{mV}$ at that time, which identified out of range of $[-30 \mathrm{mV},+30 \mathrm{mV}]$ to prove the stable thermodynamic of the dispersion system of the AuNPs. The AuNPs conducted high stability because they were protected by compound (2) as shown in (Figure 9) after storage 14 days as a surfactant agent, which occupied in a colloidal system.

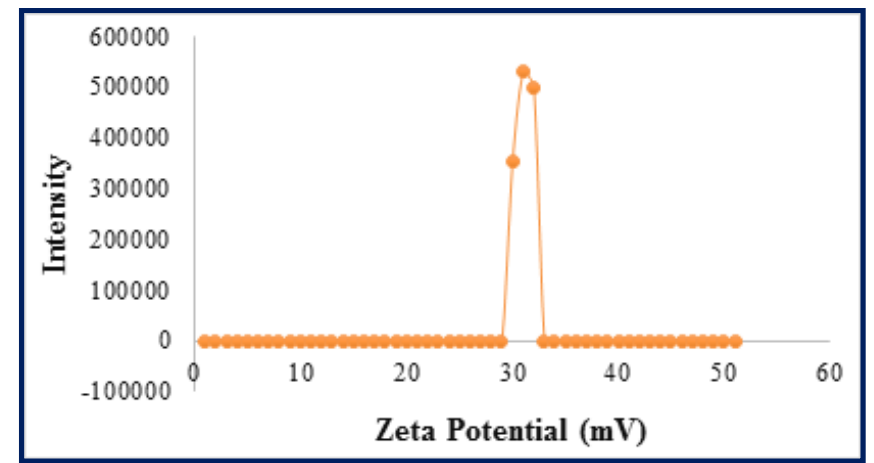

Figure 7. The Zeta potential of a colloidal dispersion

system of the AuNPs at 30 min of reaction time and storage after 14 days 


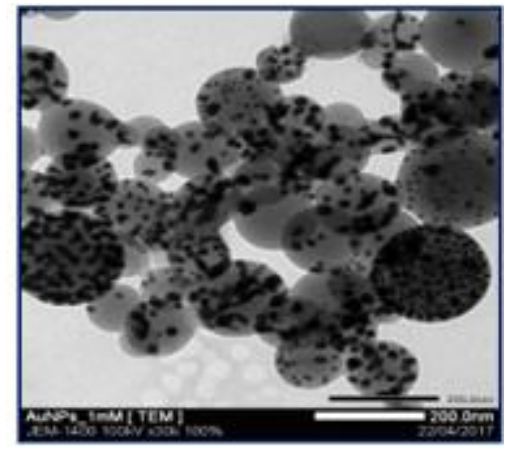

Figure 8a. The TEM images of the AuNPs at 30 min of reaction and at $50^{\circ} \mathrm{C}$

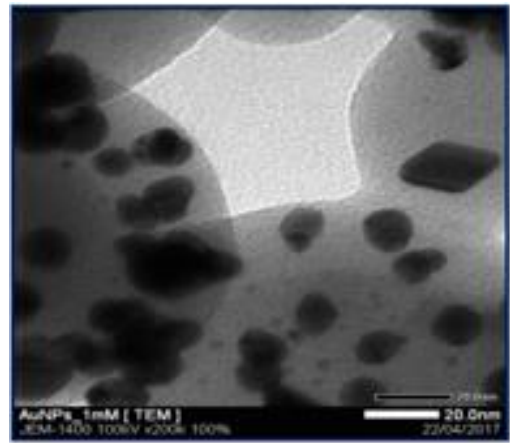

Figure 8b. The TEM image enlarged the selected AuNPs at 30 min of reaction time and at $50^{\circ} \mathrm{C}$
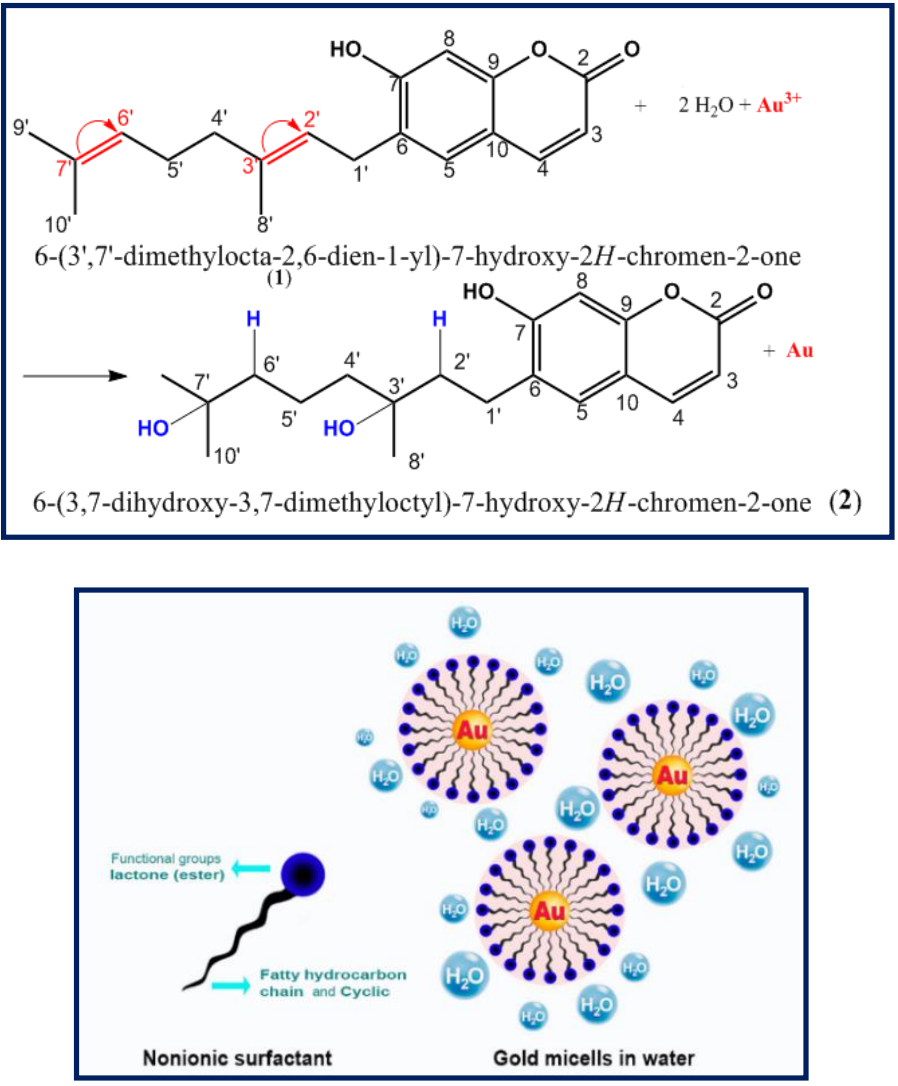

Figure 9. The reduced $\mathrm{Au}^{3+}$ to atom Au by Ostruthin via greener approach

\subsubsection{Proposed mechanics for forming and the stable thermodynamic of AuNPs}

As shown in Figure 6-10 and Figure S.18, the AuNPs formed in hydrophobic colloidal system and occupied the organic molecules, which transformed during the reaction between the $\mathrm{HAuCl}_{4}$ and Ostruthin in Figure 9, and made the role of a surfactant agent (wetting agent), which protected a colloidal system of AuNPs. The IR spectrum as shown in Figure S18, the two alkene groups in the structure of Ostruthin were absent so the Ostruthin molecules reacted with $\mathrm{HAuCl}_{4}$ and formed two tertiary alcohol groups (structure (2) in Figure 9). The structure (2) connected to an aliphatic hydrocarbon chain of eight carbons (as a hydrophobic group) and a coumarin skeleton (as a hydrophilic group), which was the role of the surface-active molecules. They formed the colloidal micelles that covered the AuNPs outside. This also proved in the TEM image of the AuNPs as shown in Figure 8a-b. The proposed mechanics of stable colloid of the AuNPs was illustrated clearly in Figure 10, which led to an increase in the electrostatic repulsions between the AuNPs and made high stability of nanoparticles of the AuNPs. 


\subsubsection{Transmission electron microscopy (TEM)}

The photo of the TEM image as shown in Figure 8a-b, the physical characteristics of AuNPs have been identified as the spherical, triangular, hexagonal distribution and sizes from 10-20 nm. The AuNPs have been covered by molecules (6-(3,7-dihydroxy-3,7-dimethyloctyl)-7-hydroxy -2Hchromen-2-one), molecules (2) as a surfactant agent which yielded during a reduction reaction. This proved new results in AuNPs about synthesizing of green gold nano via using a reducing agent that previous research articles were only used plant extracts, which included many constituents (crude extracts).

\subsubsection{Energy dispersive X-ray (EDX) spectrum}

EDX spectrum, as shown in Figure 11 and $\mathbf{S 1 9}$, indicated the colloidal dispersion system of the AuNPs was $100 \%$ of gold atoms.

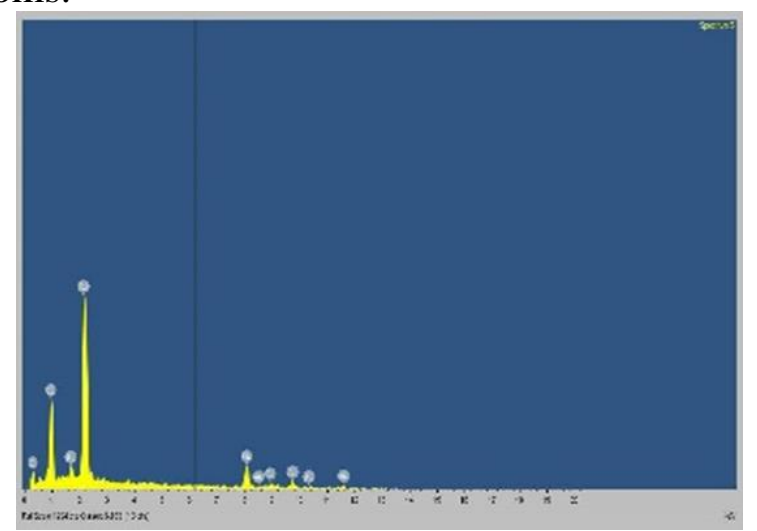

Figure 11. The EDX spectrum of the AuNPs

\subsection{Antitumor and antibacterial activity of the AuNPs}

\subsubsection{Antitumor activity}

The AuNPs were conducted again for three human cancer cell lines MCF-7, NCI H460, and Hep G2. The results presented in Figure 12-13 and Table S2. The AuNPs indicated the highest antitumor activity with the $\mathrm{IC}_{50}$ value of $65.47 \pm 3.09 \mu \mathrm{M}$ against MCF-7, moderate activity with NCI H460, and Hep G2 at different concentrations. The antitumor activity of the AuNPs was also compared with it of the extracted constituents from the Root of Luvunga Scandens in a previous article [23]. The AuNPs were exposed to higher activity than compounds, which extracted from Root of Luvunga Scandens against MCF-7 and Hep G2. The IC $_{50}$ values of Camptothecin against MCF-7, NCI H460, and Hep G2 was reported $1.81 \pm 0.09,9.17 \pm 0.41$, and $7.43 \pm 0.55 \mu \mathrm{M}$, respectively. The AuNPs can be well delivered, but the $\mathrm{HAuCl}_{4}$ contained the chlorine ions. They have affected cells and made dead of cancer cell lines.

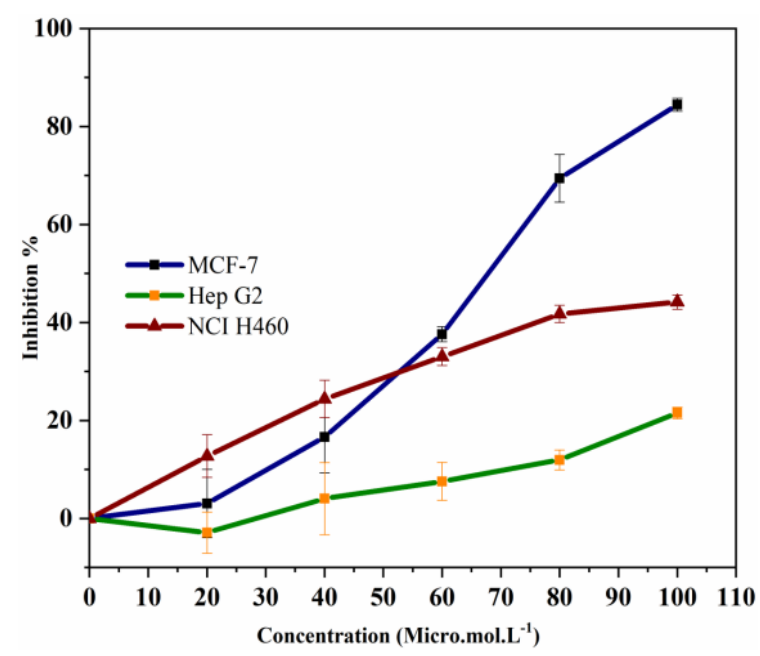

Figure. 12 The antitumor activity of the AuNPs against three human cancer cell lines 


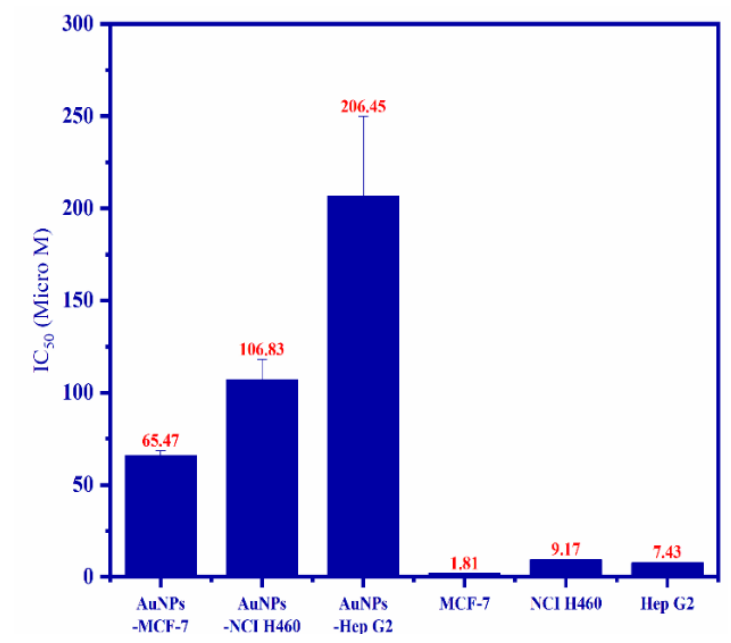

Figure 13. The $\mathrm{IC}_{50}$ values of the AuNPs and standard drug, Camptothecin against three human cancer cell lines in vitro

3.3.2. Antibacterial activity: As shown in Table 1, the AuNPs exposed the moderate inhibition against Salmonella enterica and Bacillus substilis with the inhibition zones of $10 \mathrm{~mm}$, and $10 \mathrm{~mm}$, respectively at a concentration of $0.25 \mathrm{mM}$. The data, compared to the inhibition zones of standard drug, Gentamicin were measured 16 and $18 \mathrm{~mm}$, respectively. The AuNPs had the less or no activity against Escherichia Coli and Bacillus cereus bacteria in Figure 14-15 and Table 1 at all of the concentrations.

Table 1. The antibacterial activity of AuNPs at concentration from 0.125 to $1 \mathrm{mM}$

\begin{tabular}{|c|c|c|c|c|c|c|}
\hline \multirow{4}{*}{ Bacteria } & \multicolumn{6}{|c|}{ Inhibition zone $^{[\mathrm{b}]}$} \\
\hline & \multirow[t]{3}{*}{ Drug $^{[\mathrm{a}]}$} & \multicolumn{5}{|c|}{ AuNPs } \\
\hline & & \multicolumn{5}{|c|}{ Concentration $^{[\mathrm{c}]}$} \\
\hline & & 0 & 1 & 0.5 & 0.25 & 0.125 \\
\hline Salmonella enterica & 16 & - & 8 & 8 & 10 & 8 \\
\hline Bacillus substilis & 18 & - & 8 & 8 & 10 & 9 \\
\hline Escherichia coli & 14 & - & - & - & - & 8 \\
\hline Bacillus cereus & 22 & - & - & - & - & - \\
\hline
\end{tabular}




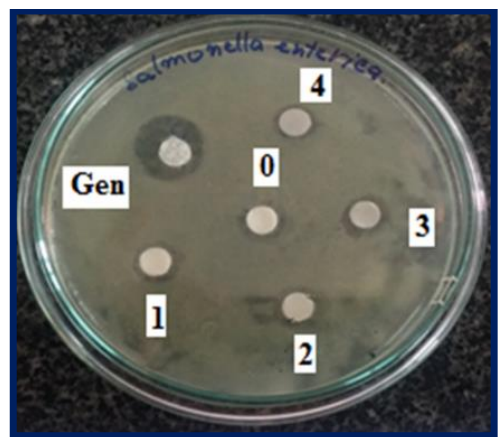

Figure 14. The antibacterial activity of the AuNPs against $S$. enterica at concentrations: (1): $1 \mathrm{mM},(2): 0.5 \mathrm{mM}$, (3): $0.25 \mathrm{mM}$, and (4): $0.125 \mathrm{mM}$; (0): negative control (water), and Gen: positive control, Gentamicin drug

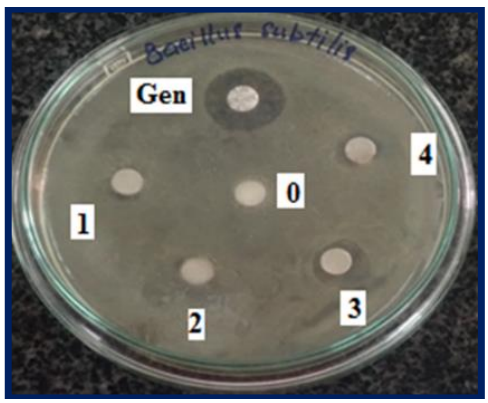

Figure 15. The antibacterial activity of the AuNPs against $B$. substilis at concentrations: (1): $1 \mathrm{mM},(2): 0.5 \mathrm{mM}$, (3): $0.25 \mathrm{mM}$, and (4): $0.125 \mathrm{mM}$; (0): negative control (water), and Gen: positive control, Gentamicin drug

\section{Conclusions}

The AuNPs were synthesized by biochemistry approaching via green reduce reaction between $\mathrm{HAuCl}_{4}$ and Ostruthin, which was extracted, isolated, and resoled structure. The AuNPs were characterized by UV-vis, FT-IR, TEM, EDX, Zeta potential, performed the antitumor activity against three human cancer cell lines, and tested antibacterial activity. The AuNPs exposed the potential antitumor activity against MCF-7 with the $\mathrm{IC}_{50}$ value of $65.47 \pm 3.09 \mu \mathrm{M}$. They also showed higher antitumor activity than that of the compounds extracted from the root of Luvunga Scandens. They indicated potential activity against Salmonella enterica and Bacillus substilis at a concentration of 0.25 $\mathrm{mM}$. In addition, the SEM image exhibited AuNPs were covered by organic molecules as the surfactant molecules being formed in the reaction between $\mathrm{HAuCl}_{4}$ and Ostruthin. Those molecules (2) made the AuNPs more stable because the Zeta potential value was conducted $+30,3 \mathrm{mV}$ after storage in 14 days. Their size and shape were 10-20 nm and face-centered-cubic, spherical, triangular, and hexagonal distribution. The best conditions for synthesized the AuNPs carried out at the concentration of $1 \mathrm{mM}, p \mathrm{H} 4$, at $50^{\circ} \mathrm{C}$, and for $30 \mathrm{~min}$. The EDX spectrum proved $100 \%$ of Gold (III) chloride trihydrate reducing to $\mathrm{Au}$ atoms by Ostruthin was the benefit approach to comply with a reduced method, being used the extract to plants forming nanoscale.

Acknowledgments: This research was supported by Faculty of Chemical Engineering, Industrial University of Ho Chi Minh City, Ho Chi Minh City Vietnam.

\section{References}

1. BANU, H., RENUKA, N., FAHEEM, S.M., ISMAIL, R., SINGH, SAADATMAND, V.Z., KHAN, S.S., NARAYANAN, K., RAHEEM, A., PREMKUMAR, K., VASANTHAKUMAR, G., Gold and Silver Nanoparticles Biomimetically Synthesized Using Date Palm Pollen Extract-Induce Apoptosis and Regulate p53 and Bcl-2 Expression in Human Breast Adenocarcinoma Cells, Biol. Trace Elem. Res. 186(1), 2018, 122-134.

2. PATRA, S., MUKHERJEE, S., BARUI, A.K, GANGUlY, A., SREEDHAR, B., PATRA, C.R., Green synthesis, characterization of gold and silver nanoparticles and their potential application for cancer therapeutics, Mater Sci Eng C. 53, 2015, 298-309.

3. RAJESHKUMAR, S., Anticancer activity of eco-friendly gold nanoparticles against lung and liver cancer cells, J. Genet. Eng. Biotechnol. 14, 2016, 195-202. 
4. KUMAR, K.P., PAUL, W., SHARMA, C.P., Green synthesis of gold nanoparticles with Zingiber officinale extract: Characterization and blood compatibility, Process Biochem. (Oxford, U. K.) 46(10), 2011, 2007-2013.

5. WANG, L., XU, J., YAN, Y., LIU, H., KARUNAKARAN, T., LI, F., Green synthesis of gold nanoparticles from Scutellaria barbata and its anticancer activity in pancreatic cancer cell (PANC-1), Artif. Cells, Nanomed., Biotechnol., 47(1), 2019, 1617-1627.

6. SARKAR, S., KOTTEESWARAN, V., Green synthesis of silver nanoparticles from aqueous leaf extract of Pomegranate (Punica granatum) and their anticancer activity on human cervical cancer cells, Adv. Nat. Sci.: Nanosci. Nanotechnol. 9, 2018, 25014-25023.

7. WANG, W., YAO, F., WANG, D., ZHOU, X., WANG, X., ZHAO, C., FANG, M., CAI, J., Biosynthesis of Gold Nanoparticles Using Pleurotus ostreatus extract with Their Electrochemical Activity of Detection of Carbendazim in vegetable, Int. J. Electrochem. Sci., 12, 2017, 842-851. doi: 10.20964/2017.02.23

8. MIRI A., DARROUDI, M., ENTEZARI, R., SARANI, M., Biosynthesis of gold nanoparticles using Prosopis farcta extract and its in vitro toxicity on colon cancer cells, Res. Chem. Intermed. 44(5), 2018, 3169-3177.

9. FILIP, G. A., MOLDOVAN, B., BALDEA, I., OLTEANU, D., SUHAROSCHI, R., DECEA, N., MIHALA, C.C., GALE, E., CENARIUF, M., CLICHICIA, S., DAVID, L., UV-light mediated green synthesis of silver and gold nanoparticles using Cornelian cherry fruit extract and their comparative effects in experimental inflammation, J. Photochem. Photobiol., B, 191, 2019, 26-37.

10. POOJARY, M.M., PASSAMONTI, P., ADHIKARI, A.V., Green Synthesis of Silver and Gold Nanoparticles Using Root Bark Extract of Mammea suriga: Characterization, Process Optimization, and Their Antibacterial Activity, BioNanoSci. 6(2), 2016, 110-120.

11. MITTAL, A.K., CHISTI, Y., BANERJEE, U.C., Synthesis of metallic nanoparticles using plant extracts, Biotechnol. Adv., 31(2), 2013, 346-356.

12. JUNIOR, V.E.D.S., TARGINO, A.G.R., FLORES, M.A.P., DI'AZ, J.M.R., TEIXEIRA, J.A., HEIMER, M.V., PESSOA, H.D.L.F., GALEMBECK, A., ROSENBLATT, A., Antimicrobial activity of silver nanoparticle colloids of different sizes and shapes against Streptococcus mutans, Res. Chem. Intermed. 43, 2017, 5889-5899.

13. MIRI, A., DARROUDI, M., ENTEZARI, R., SARANI, M., Biosynthesis of gold nanoparticles using Prosopis farcta extract and its in vitro toxicity on colon cancer cells, Res. Chem. Intermed., 44, 2018, 3169-3177.

14. WACŁAWEK, S., GONČUKOVÁ, Z., ADACH, K., FIJAŁKOWSKI, M., ČERNÍK, M., Green synthesis of gold nanoparticles using Artemisia dracunculus extract: control of the shape and size by varying synthesis conditions, Environ. Sci. Pollut. Res., 25(24), 2018, 24210-24219.

15. RAHMAN, A., KUMAR, S., BAFANA, A., DAHOUMANE, S. A, JEFFRYES, C., Individual and combined effects of extracellular polymeric substances and whole cell components of chlamydomonas reinhardtii on silver nanoparticle synthesis and stability, Molecules. 24, 2019, 956-973.

16. Pérez, B.A., Hernández, L.G., Ortega, P.A.R., Islas, D.A., Green Synthesis of Gold Nanoparticles (AuNPS) Using the Extract of Sedum Praealtum, ECS Trans., 81(1), 2018, 321-320.

17. BONIGALA, B., USHA, K.M., VIJAYALAKSHMI, M., RAO, K.R.S.S., RAVI, V.A., PODA, S., Green synthesis of silver nanaoparticles from leaf extract of Cascabela thevetia, physicochemical characterisation and antimicrobial activity, J. Pharm. Res. (Mohali, India) 10(6), 2016, 410-417.

18. MOUSAVI, B., TAFVIZI, F., BOSTANABAD, S.Z., Green synthesis of silver nanoparticles using Artemisia turcomanica leaf extract and the study of anti-cancer effect and apoptosis induction on gastric cancer cell line (AGS), Artif. Cells, Nanomed., Biotechnol. 46, 2018, 499-510. https://doi.org/10.1080/21691401.2018.1430697.

19. NAMVAR, F., AZIZI, S., MOHAMAD, R., BOROUMAND, M.A., SOLTANI, M., MOSHFEGH, F., Nanosized silver-palm pollen nanocomposite, green synthesis, characterization and antimicrobial activity, Res. Chem. Intermed., 42, 2015, 1571-1581. 
20. WADHWANI, S.A., GORAIN, M., BANERJEE, P., SHEDBALKAR, U.U., SINGH, R., KUNDU, G.C., CHOPADE, B.A., Green synthesis of selenium nanoparticles using Acinetobacter sp. sW30: optimization, characterization and its anticancer activity in breast cancer cells, Int. J. Nanomed. 12, 2017, 6841-6855.

21. PINTO, R.J.B., LUCAS, J.M.F., MORAIS, M.P., SANTOS, S.A.O., SILVESTRE, A.J.D., MARQUES, P.A.A.P., FREIREA, C.S.R., Demystifying the morphology and size control on the biosynthesis of gold nanoparticles using Eucalyptus globulus bark extract, Ind. Crops Prod. 105, 2017, 83-92.

22. DUBE, T., KUMAR, N., KOUR, A., MISHRA, J., SINGH, M., PRAKASH, B., PANDA, J.J., Gold Nano-/Micro-Roses on Levodopa Microtubes for SERS-Based Sensing of Gliomas, Appl. Nano Mater. 2(5), 2019, 2663-2678.

23. AL-ZIKRI, P.N.H., TAHER, M., SUSANTI, D., REZALI, M.F., READ, R.W., SOHRAB, M.H., HASAN, C.M., AHMAD, F., Cytotoxic tirucallane triterpenes from the stem of Luvunga scandens, Brazilian Journal of Pharmacognosy, 24(5), 2014, 561-564.

24. TAHER, M., AL-ZIKRI, P.N.H., SUSANTI, D., ICHWAN S.J.A., REZALI, M.F., Effects of Triterpenoids from Luvunga scandens on Cytotoxic, Cell Cycle Arrest and Gene Expressions in MCF7 Cells, Nat Prod Sci., 22(4), 2016 293-298.

25. SIRINUT, P., PETCHKONGKEAW, A., ROMSAIYUD, J., PRATEEPTONGKUM, S., THONGYOO, P., Phytochemical Constituents from the Root of Luvunga Scandens and Biological Activity Evaluation, Nat. Prod. Commun. 12(9), 2017, 1483-1484.

26. AN, T.N.M., TUOI, D.T.H, TRUONG, L.H., DUNG, L.T., TUYEN, P.N.K., MINH, P.N., TRI, M.D., PHAT, N.T., Acridone alkaloids from the rhizomes of Luvunga scandens (Roxb.) Buch. Ham., Nat Prod Res. 33(15), 2019, 2176-2181.

27. AN, T.N.M., ALAM, M., SON, N.V., CUONG, N.V., QUANG, N.M., TRI, M.D., TAN, L.V., Synthesis, Physical Chemistry, Molecular Docking,Bioactivities and Antioxidant Activity of $\boldsymbol{\alpha}$-Amino Phosphonates Based on Phenothiazine Using PEG-400 as Green Catalyst, ChemistrySelect, 4(31), 2019, 8915-8920.

28. ALEXANDRA, A., MARIA, G., SORIN, R., AURORA, M., GERTRUD, A., LEXANDRA, P., CSABA, V. J.R., IOAN, P., OSSI, H., MARIA, T.C., In-vitro Antibacterial Activity of Novel Nanostructured Composites Based on Forsterite and Silver Nanoparticles, Rev.Chim.71(1), 2020, 1321.

29. VICHAI, V., KIRTIKARA, K., Sulforhodamine B colorimetric assay for cytotoxicity screening, Nat. Protoc. 1(3), 2006, 1112-1116.

30. STEFANIA,F. B., OCTAVIAN, T.O., LAURA,I.S., CONSTANTIN, D., GABRIEL, S., STELIAN, B., BOGDAN, S., FLORICA, B., S-Alkylated 1,2,4-Triazoles Derivatives Synthesis, spectral analysis and cytotoxicity evaluation, Rev.Chim. 70(1), 2019, 13-17.

31. DALIANA, M., STEFANA, A., IOANA, Z.P., BRIGITTA, K., ALEXANDRA, G., STVAN, Z., CRISTINA, D., VALENTINA, B., ZORITA, D., ALEXANDRA, S., ALEXA, V., CORINA, D., An in vitro Evaluation of Apigenin and Apigenin-7-O-glucoside Against HeLa Human Cervical Cancer Cell Line, Rev. Chim.71(2), 2020, 140-145.

32. MARIA, P., ALINA, H., ADELINA, C., SIMONA, N., MIRELA, V., VALENTINA, B., DANIELA, I., LUCIAN, N., CRISTINA, T., VIRGIL, P., Thyme Leaves Aqueous Extract and its Formulations A comparative study based on chemical structures and biological activity, Rev. Chim. 70(5), 2019, 1875-1878.

33. NAGAJYOTHI, P.C., LEE, S.E., AN, M., LEE, K.D., Green Synthesis of Silver and Gold Nanoparticles Using Lonicera Japonica Flower Extract, Bull. Korean Chem Soc. 33(8), 2012, 26092612.

Manuscript received: 29.03 .2020 